\title{
Metamokymasis pradiniame ugdyme: mokslinès literatūros analizė
}

\author{
Jovita Matulaitienè
}

Vytauto Didžiojo universitetas, Socialinių mokslų fakultetas, K. Donelaičio g. 58, 44248 Kaunas, jovita.matulaitiene@alumni.vdu.lt

Anotacija. Straipsnyje nagrinejamas pradiniame ugdyme vykstantis metamokymasis, kaip svarbus kognityvinis procesas, kurio metu besimokantieji geba mokytis savarankiškai, o ịgytos žinios ir igūdžiai padeda tapti mokančiais mokytis asmenimis. Tyrime analizuojami pradinių klasių mokinių savarankiško mokymosi komponentai, ịgyvendinimo praktikos, problematika. Tyrimas pasirinktas atsižvelgiant ị edukologijos mokslo tyrimuose augantį dèmesį metamokymosi strategijų taikymui ir kylantiems iššūkiams ankstyvame amžiuje.

Esminiai žodžiai: pradinis ugdymas, metamokymasis, metakognityvinès strategijos, metakognityvinis suvokimas, metakognicija vaikystejje.

\section{Ivadas}

Metamokymasis - neatsiejama šiuolaikinio švietimo dalis ir kognityvinès psichologijos sritis analizuojant vienas svarbiausių - mokymosi mokytis ir informacijos supratimo - kompetencijų jau pradiniame ugdyme (Nieto-Márquez ir kt., 2020). Metamokymosi tyrimai vykdomi nuo XX a. šeštojo dešimtmečio (Piaget, 1954; Flavell, 1979; Vygotsky, 1978; Bandura, 1989), tačiau, siekiant geriau suprasti, kaip sukurti vis geresnę mokymosi patirtị, išlieka aktualūs ir nuolat plètojami ir XXI a. (Morawska ir kt., 2019). Pastaruoju metu metamokymasis ir jo reguliavimas pradiniame ugdyme yra pagrindinis švietimo mokslininkų ir praktikų tyrimų objektas siekiant susisteminti ir pagrịsti būdus, padedančius plètoti vaikų metakognityvines žinias ir jų taikymą kasdieniame mokymesi. Šie būdai skirstomi ị kelias grupes: metakognityvinių žinių plètojimas; tiesiogiai modeliuoti metakognityvinio reguliavimo procesai; kuriamos sudètingos situacijos, kurios natūraliai skatina vaikų metakognityvius samprotavimus ir veiksmus; kuriama bendra vaikų 
žaidimų, bendravimo ir mokymosi aplinka; skatinamas bendras vaikų ir suaugusiųjų dalyvavimas mokymosi veikloje (Monkevičienè, Vildžiūnienè ir Valinčienė, 2020).

Atlikti tyrimai rodo, kad vaikų metakognityvių reguliavimo būdų raida ikimokykliniame ir pradiniame ugdyme yra sèkmingo mokymosi mokytis pagrindas. Marulis, Palincsar, Berhenke ir Whitebread (2016) atskleidè, kad metakognityvinių žinių komponentai yra labai artimi ł̇ūdžiams, reikalingiems mokytis mokykloje. Nustatyta, kad metapažinimas skatina savarankišką mokymąsi (Robson, 2010, 2016) ir daro įtaką vaiko individualaus mokymosi strategijų pasirinkimui (Chatzipanteli, Grammatikopoulos ir Gregoriadis, 2014). Metažinojimas turi ir tam tikrą poveikị kritinio mąstymo kokybei (Magno, 2010), santykiui su geresniais ir efektyvesniais problemų sprendimo ịgūdžiais (Lee, Teo ir Bergin, 2009).

Bernardas, Proustas ir Clémentas (2015) ịvardija du požiūrius ị vaikų metakognityvinị reguliavimą. Pirmuoju požiūriu teigiama, kad vaikų metakognityvinis reguliavimas galimas tik tada, kai vaikai labai aiškiai supranta savo žinių procesus (suvokimą, atmintị, samprotavimus ir kt.), tai yra tada, kai jie ugdo koncepcija pagrịstus metakognityvinius gebėjimus. Kitas požiūris yra paremtas tyrimais, rodančiais, kad vaikai turi patirtimi pagrịstų metakognityvinių žinių (pavyzdžiui, vaikai žino, ką buvo sunkiau ar lengviau padaryti). Remiantis pirmuoju požiūriu, metakognityvinis reguliavimas galimas maždaug šešerių metų amžiaus, o antruoju požiūriu, kad kai kurios metakognityvinio reguliavimo formos atsiranda daug anksčiau (Monkevičienè, Vildžiūnienè ir Valinčienė, 2020).

Nors vis dar plačiai diskutuojama ir nèra vienos nuomonès, kuriame amžiaus etape metamokymasis prasideda, tačiau bendrai sutariama, kad vis daugiau demesio būtina skirti metakognityviniam suvokimui ankstyvame amžiuje, siekiant, kad vaikai gebètų suprasti bet kurị mokomąjį dalyką ir suvoktų, kaip pažinimo ịgūdžiai leidžia valdyti jų mokymąsi (Ozturk ir Gural, 2016; Siswati ir Corebima, 2017). Savireguliacijos intervencijos yra taikomos jau pradinės mokyklos aplinkoje ir dažniausiai remiasi socialinio pažinimo teorija (Dignath ir Büttner, 2008; Dignath ir kt., 2008). Dauguma atliktų tyrimų padejjo atskleisti vaikų metakognityvinio reguliavimo komponentų raidą ankstyvoje vaikysteje; šie komponentai įvardijami kaip vèlesnio sèkmingo mokymosi rodikliai (McClelland ir Cameron, 2012; Mischel ir kt., 2011; Moffitt ir kt., 2011; Rowe ir kt., 2018).

Analizuotų tyrimų metu pastebèta, kad pradinių klasių mokinių metamokymasis ir jo reguliavimas buvo tiriami labiau eksperimentinèse, modeliuojamose situacijose nei mokytojų inicijuotose kasdienėse pamokų veiklose mokyklose (Bernard ir kt., 2015; Robson, 2010). Mokslininkai ịvardijo ịvairius būdus, kaip skatinti metamokymosi reguliavimo vystymąsi (Hyerle, 2014; Perry, Thauberger ir Hutchinson, 2010; Roebers, 2017), tačiau mokytojams skatinti vaikų metamokymosi reguliavimą ir plètrą vis dar lieka didelis iššūkis.

Mokslinio tyrimo problema. Atsižvelgiant ị augantị metamokymosi poreikị tobulinant mokymąsi ir mokymą jau ankstyvame amžiuje, kyla poreikis vis labiau sistemingai tirti metamokymosi galimybes ir tendencijas šių dienų mokymesi. Taigi, mokslinio 
tyrimo problema - kokie metamokymosi komponentai yra taikomi ir adaptuojami šiuolaikiniame pradiniame ugdyme?

Tyrimo objektas - metamokymosi komponentų taikymas pradiniame ugdyme.

Tyrimo tikslas - išanalizavus atliktus tyrimus, atskleisti metamokymosi komponentus ir jų charakteristikas siekiant giliau suprasti šio mokymosi realizavimo galimybes pradiniame ugdyme.

\section{Tyrimo uždaviniai:}

1. Analizuojant atliktus tyrimus ịvardyti pradiniame ugdyme taikomus tyrimų metodus.

2. Išskirti metamokymosi komponentus, kurie padeda ugdyti pradinių klasių mokinių savarankiško mokymosi gebejimus.

3. Ivardyti pradinių klasių mokiniams kylančius metamokymosi iššǔkius.

4. Atlikus literatūros analizę, toliau tyrimo metu siekiama analizuoti pradiniame ugdyme taikomus metamokymosi metodus, jų charakteristikas, kylančius iššūkius ir numatyti tikslingas tolimesnes tyrimų kryptis, kurios leistų plètoti metamokymosi taikymą jau pradinio ugdymo procese.

\section{Metodologija}

Tyrimo metodai. Duomenų analizei buvo taikoma kokybinè turinio analizės technika, kuri yra tyrejų plačiai naudojama ịvairiems tekstams tirti (Berg ir Lune, 2012; Mayring, 2014). Tyrimo metu, analizuojant skirtingus metamokymosi pradiniame ugdyme atliktus tyrimus, atsižvelgiant ị jų turinị ir reikšmes, buvo išskirtos pagrindinės kategorijos, kurios vèliau interpretuojamos siekiant geriau suvokti metamokymosi idejjos komponentus, jų praktinį taikymą, problematiką bei reikalingas ateities mokymo/si kryptis.

Mokslinès literatūros atranka. Siekiant užtikrinti kuo išsamesnę literatūros paiešką elektroninèse švietimo duomenų bazėse buvo analizuoti (paieška atlikta $2020 \mathrm{~m}$. lapkričio-2021 m. sausio mènesiais) Academic Search Complete (EBSCO), Cambridge Core, Education Source (EBSCO), ERIC ir ScienceDirect tyrimų duomenys bei teorinès apžvalgos. Siekiant sumažinti sąvokos diferenciacijos neryškumo padarinius, paieška buvo atliekama pagal konkrečiai ịvardytus terminus. Kiekvieną iš 6 raktinių / esminių žodžių rinkinị, susijusị su mokymusi, žymi konkretūs terminai („metalearning“, „metalearning experience“, „metacognitive strategies“, „metacognitive awareness“, „metacognition in childhood“) ir nurodomos konkrečios tiriamųjų amžiaus grupès („pre-school education“, „primary education“), kuriose tiriami mokymosi ypatumai. Straipsniai, kuriuose šie žodžiai minimi abstrakčiai, buvo įtraukti į pirminę atranką. Straipsniai, paskelbti recenzuojamuose žurnaluose 2006-2021 m., parašyti lietuvių arba anglų kalba ir skirti amžiaus kategorijai 6-11 metų (t. y. pradinis išsilavinimas; 1-6 klasės JAV sistemoje ir 6-11 metų Europos šalių sistemose). Paieškos metodai leido surinkti maždaug 587 nuorodas, 
kurios atitiko paieškos reikalavimus. Atrenkant publikuotus straipsnius tyrimui, taikyti autoriaus pasirinkti ittraukimo ir atmetimo kriterijai.

\section{1 lentelè}

Literatūros apžvalgos ịtraukimo ir atmetimo kriterijai

\section{İtraukimo kriterijai}

Tyrimai pateikia aiškius duomenis, kad nagrinejamas metamokymasis (pasirinkimas grindžiamas pavadinimu, tyrimo tikslu ir raktiniais / esminiais žodžiais)

Tiriamųjų amžius nuo 6 iki 11 metų amžiaus

Vyksta formalus mokymasis pradinio ugdymo mokykloje

Tiriami moksleiviai, kuriems nèra diagnozuoti mokymosi sutrikimai

Analizuojami viso teksto ir atvirosios prieigos straipsniai

Tyrimų straipsniai išleisti lietuvių arba anglų kalbomis

Straipsniai publikuojami recenzuojamame mokslo leidinyje

\section{Atmetimo kriterijai}

Tyrimo rezultatai neatskleidžia metamoky$\mathrm{mą/si} \mathrm{apibūdinančių} \mathrm{požymių}$

Tyrimas skirtas vyresniems nei pradiniu klasių mokiniams

Tyrimo metu mokinių metakognityvių gebèjimų lygio nustatymui naudojama mechaninè iranga, kuri matuoja biologines vaiko reakcijas ị paskirtas užduotis

Tyrimai, kai imtị sudare asmenys, kuriems diagnozuoti mokymosi sutrikimai

Nepilnos prieigos straipsniai

Tyrimų straipsniai išleisti ne lietuvių ar anglų kalbomis

Straipsniai publikuojami nerecenzuojamame mokslo leidinyje

Taikant tolesnius atrankos kriterijus, atrenkant rankiniu būdu, nuorodų skaičius sumažèjo iki 152. Paskutiniame tyrimo etape buvo pašalinta 120 straipsnių, kuriuose nurodoma, jog mokymasis vyko neformalioje aplinkoje, teikiama konferencijų santrauka, komentarai, ataskaitos. 32 publikacijose buvo apibrěžta informacija apie kintamuosius, kurie buvo tiriami per pastarąji dešimtmetị ir buvo susiję su metamokymusi pradinèse klasėse. Siekiant sukurti skirtingų studijų apžvalgą, tyrimui atrinkti straipsniai koduojami pagal turinị, siekiant trumpai aprašyti kiekvieno tyrimo pagrindinius bruožus ir rezultatus. Turinio kodavimas apėmè šiuos dalykus: šalį, kurioje buvo atlikta intervencija, tiriamųjų amžių, tyrimo sritis, taikytus tyrimo metodus, metamokymąsi liudijančius bruožus, išskirtus rezultatus, rekomendacijas tolimesniems tyrimams.

Tiriamujų amžius. Pastaraisiais metais vis plačiau analizuojant mažų vaikų metakognityvumą, buvo įrodyta, kad metakognityvus mąstymas vystosi ankstyvaisiais vaikų gyvenimo metais, jau priešmokykliniame ir pradiniame ugdyme (Bryce ir Whitebread, 2012; Larkin, 2010; Lockl ir Schneider, 2006; 2008; Akaydin ir kt., 2020; Stonkuvienė, 2018; Nelson ir Fyfe, 2019). Priešmokyklinis ir pradinis ugdymas yra orientuotas $\mathfrak{i}$ 
vaiką, jo poreikius ir gebejimus. Šiame vystymosi laikotarpyje formuojasi svarbiausi vaikų pažinimo, stebejimo, planavimo ir kontrolès procesai, kurie daro įtaką jų elgesiui ir verbalizacijai tolimesniame mokymesi (Rowe, 2018). Siekiant kokybiško jauniausių visuomenès narių mokymo ir mokymosi, atliekamame tyrime yra tikslinga ịtraukti ir priešmokykliniame ugdyme atliktus tyrimus, kurių rezultatuose buvo identifikuotos temos ir atskleista tematika, leidžianti plačiau apžvelgti ir suvokti analizuojamus metamokymosi komponentus ir charakteristikas ankstyvame amžiuje. Straipsnyje tiriamųjų amžius yra apibréžiamas nuo 3 iki 10 metų, t. y. priešmokyklinio ir pradinio ugdymo mokiniai. Mokslininkų (McClelland ir Cameron, 2012; Nelson ir Fyfe, 2019) nuomone, priešmokyklinis ir pradinis ugdymas yra švietimo pagrindas, kuriame integralus ir $\mathfrak{i}$ besimokantijji orientuotas ugdymas nukreipia j̣ sẻkmingą ateitị, o mokymosi proceso valdymas tampa pagrindine besimokančiojo veikla, kuri daro ịtaką visaverčiam asmenybès vystymuisi. Ankstyvame mokymosi procese moksleiviu gebejimas sutelkti dèmesị ir nukreipti elgesị ị mokymosi užduotis suteikia pagrindą tinkamai socialinei ir akademinei raidai.

\section{Tyrimo rezultatai ir diskusijos}

Siekiant nustatyti metamokymesi taikomus mokymosi metodus, jų taikymo praktikoje galimybes ir kylančius mokymosi iššūkius pradinio ugdymo mokiniams, atliktas kokybinis mokslinių tyrimų turinio analizès tyrimas. Atlikta tyrimų analizė leido nustatyti pagrindinius požymius, kaip metamokymasis yra suvokiamas, apibrěžiamas ir taikomas pradinio ugdymo procese skirtingose Europos ir pasaulio valstybėse. Nors literatūroje apie kognityvinę raidą buvo vartojami ịvairūs metamokymosi konceptualizavimai, ši sąvoka paprastai buvo apibrèžta kaip bet kokios žinios ar pažintiné veikla, kurios objektas yra sumanus naujos informacijos pažinimo reguliavimas (Schneider ir Artelt, 2010). Remiantis šia konceptualizacija, metapažinimas reiškia žinias apie jų pačių informacijos apdorojimo ịgūdžius, žinias apie kognityvinių užduočių pobūdị ir strategijas, kaip atlikti reikiamas užduotis.

Atliktų tyrimų rezultatai pateikiami 2 ir 3 lentelèse, vèliau interpretuojami. Nustatyta, kad yra įvairių priemonių, kuriomis buvo fiksuojama tai, ką vaikai žino apie pažintinę veiklą, savo pažinimo ịgūdžius, mokymąsi. Metakognityvinių žinių matavimui daugelyje tyrimų dažniausiai buvo naudojami interviu arba klausimynai, rečiau užduočių atlikimo stebejjimas, vaizdo ịrašų analizè.

Pastebèta, kad nepaisant vis didèjančių metakognityvumo tyrimų ịvairiose amžiaus grupèse ir srityse (Batenas ir kt., 2017; Dignath ir Büttner, 2008; Marulis ir kt., 2016; Roebers, 2017; „Whitebread“ ir „Coltman“, 2010; ir kt.) metamokymasis, kaip atskiras objektas, tyrimuose analizuojamas retai. Dažniausiai nagrinejjamas atliekant tyrimus mokytojų modeliuojamose situacijose, kurių tikslas buvo ugdyti tyrinèjimo, suvokimo, 
mokymosi, planavimo ịgūdžius, problemų sprendimo ịgūdžius ar konceptualų supratimą, matematinį raštingumą ar kalbų mokymąsi.

Metamokymosi komponentai ir ju charakteristikos. Metamokymasis dažniausiai ìvardijamas kaip skètinis terminas, apimantis struktūras, susijusias su mąstymo procesais ir informacija, vykstantis skirtingų socialinių ir švietimo kontekstų îvairovëje (Leader, 2008). Edukologijos mokslininkų atliktų tyrimų rezultatai rodo, kad metamokymasis jau ankstyvame amžiuje turi teigiamą poveikị sèkmingam vaikų mokymuisi tokiose srityse, kaip skaitymas, kalbų mokymasis, matematika, gamtos mokslai ir problemų sprendimas (Nieto-Marquez ir kt., 2020; Akaydin ir kt., 2020; Marulis ir kt., 2016; Mansueto ir kt., 2019). Kai vaikai suvokia savo mokymąsi, pradeda kurti mokymosi strategijas (arba mokosi naudotis), kurios atitinka jų mokymosi tikslus. Jie mokosi pasirinkti, struktūruoti ir kaupti informaciją iš pamokų ir tekstų, turẻdami omenyje jų vélesnį naudojimą. Tai turi ịtakos mokymosi turinio suvokimo būdams, mokomasi naudoti supratimo strategijas, kurios padeda sąmoningai pagerinti supratimą ir formuoti žinių struktūras pagal mokymosi tikslų reikalavimus. Keletas tokių strategijų pavyzdžių: išankstinių žinių ir mokymosi strategijų aktyvinimas, esmès ir pagrindinių idejų paieška, ryšių ir išvadų kūrimas, supratimo lygio stebejjimas ir klausimų ar taisomųjų veiksmų atlikimas, kai nepavyksta atlikti užduoties (Annevirta ir kt., 2007). Atliekant metamokymosi tyrimų analizę, toliau ịvardijami šie su metakognityvine veikla pradiniame ugdyme susiję metamokymosi komponentai, kurie yra taikomi skirtingose Europos ir pasaulio šalyse bei egzistuoja skirtinguose tyrimų kontekstuose; jie pateikiami 2 lentelëje.

\section{2 lentelè}

Itrauktu tyrimu analizes rezultatai

\begin{tabular}{|c|c|c|c|c|c|}
\hline Autorius & $\begin{array}{l}\text { Tiriamujuc } \\
\text { amžius/ } \\
\text { klasè }\end{array}$ & Šalis & $\begin{array}{c}\text { Tyrimo } \\
\text { kontekstas }\end{array}$ & $\begin{array}{c}\text { Analizuojami metamokymosi } \\
\text { komponentai/aspektai }\end{array}$ & $\begin{array}{l}\text { Tyrimo } \\
\text { tipas }\end{array}$ \\
\hline $\begin{array}{l}\text { Nieto-Márquez ir } \\
\text { kt., } 2020\end{array}$ & $\begin{array}{l}3 \text { klasės } \\
\text { mokiniai }\end{array}$ & Ispanija & $\begin{array}{l}\text { Matemati- } \\
\text { nis raštin- } \\
\text { gumas }\end{array}$ & $\begin{array}{l}\text { - Metakognityvinės žinios; } \\
\text { - Metakognityvinis reguliavimas; } \\
\text { - Metakognityvinis suvokimas. }\end{array}$ & $\begin{array}{l}\text { Kiekybinis } \\
\text { tyrimas }\end{array}$ \\
\hline $\begin{array}{l}\text { Nelson ir Fyfe, } \\
2019\end{array}$ & $\begin{array}{l}1 \text { klasės } \\
\text { mokiniai }\end{array}$ & $\begin{array}{l}\text { Jungtinès } \\
\text { Amerikos } \\
\text { Valstijos }\end{array}$ & $\begin{array}{l}\text { Matemati- } \\
\text { nis raštin- } \\
\text { gumas }\end{array}$ & $\begin{array}{l}\text { - Mokymosi stebejimas; } \\
\text { - Strategiškai kontroliuojamas } \\
\text { sprendimų prièmimas; } \\
\text { - Mokymosi refleksija. }\end{array}$ & $\begin{array}{l}\text { Kokybinis } \\
\text { tyrimas }\end{array}$ \\
\hline $\begin{array}{l}\text { Bonnett ir kt., } \\
2017\end{array}$ & 8 metai & $\begin{array}{l}\text { Jungtinè } \\
\text { Karalystė }\end{array}$ & $\begin{array}{l}\text { Matemati- } \\
\text { nis raštin- } \\
\text { gumas }\end{array}$ & $\begin{array}{l}\text { - Metakognityvinès žinios; } \\
\text { - Refleksija; } \\
\text { - Kūrybiškumas. }\end{array}$ & $\begin{array}{l}\text { Kokybinis } \\
\text { tyrimas }\end{array}$ \\
\hline Rieser ir kt., 2016 & $\begin{array}{l}7-10 \\
\text { metų }\end{array}$ & Vokietija & $\begin{array}{l}\text { Visa } \\
\text { apimantis } \\
\text { mokymasis }\end{array}$ & $\begin{array}{l}\text { - Mokymo kokybė; } \\
\text { - Mokytojų skatinimas; } \\
\text { - Mokytojų dèmesingumas moki- } \\
\text { nių mokymuisi. }\end{array}$ & $\begin{array}{l}\text { Kiekybinis } \\
\text { tyrimas }\end{array}$ \\
\hline
\end{tabular}




\begin{tabular}{|c|c|c|c|c|c|}
\hline Autorius & $\begin{array}{l}\text { Tiriamujuc } \\
\text { amžius/ } \\
\text { klasė }\end{array}$ & Šalis & $\begin{array}{c}\text { Tyrimo } \\
\text { kontekstas }\end{array}$ & $\begin{array}{l}\text { Analizuojami metamokymosi } \\
\text { komponentai/aspektai }\end{array}$ & $\begin{array}{l}\text { Tyrimo } \\
\text { tipas }\end{array}$ \\
\hline $\begin{array}{l}\text { Cornoldi ir kt., } \\
2015\end{array}$ & $\begin{array}{l}8-10 \\
\text { metuc }\end{array}$ & Italija & $\begin{array}{l}\text { Skaičiavimo } \\
\text { problemų } \\
\text { sprendimas }\end{array}$ & $\begin{array}{l}\text { - Metakognityvūs įsitikinimai; } \\
\text { - Darbinè atmintis; } \\
\text { - Mokymosi problemų sprendimas. }\end{array}$ & $\begin{array}{l}\text { Kokybinis } \\
\text { tyrimas }\end{array}$ \\
\hline Baas ir kt., 2015 & $\begin{array}{l}9-10 \\
\text { metų }\end{array}$ & Olandija & $\begin{array}{l}\text { Visa } \\
\text { apimantis } \\
\text { mokymasis }\end{array}$ & $\begin{array}{l}\text { - Mokinių motyvacija mokytis; } \\
\text { - Savarankiškas mokymasis; } \\
\text { - Reflektyvus dialogas mokymosi } \\
\text { procese. }\end{array}$ & $\begin{array}{l}\text { Kiekybinis } \\
\text { tyrimas }\end{array}$ \\
\hline Bares, 2011 & $\begin{array}{l}8-10 \\
\text { metuc }\end{array}$ & $\begin{array}{l}\text { Jungtinès } \\
\text { Amerikos } \\
\text { Valstijos }\end{array}$ & $\begin{array}{l}\text { Visa } \\
\text { apimantis } \\
\text { mokymasis }\end{array}$ & $\begin{array}{l}\text { - Kognityvinè-elgesio terapija } \\
\text { vaikams; } \\
\text { - Metakognityviniai gebejimai } \\
\text { vaikystėje; } \\
\text { - Lengvesni mokymosi sprendimai. }\end{array}$ & $\begin{array}{l}\text { Kokybinis } \\
\text { tyrimas }\end{array}$ \\
\hline Geurten, 2016 & $\begin{array}{l}9-10 \\
\text { metų }\end{array}$ & Belgija & $\begin{array}{l}\text { Atminties } \\
\text { procesai }\end{array}$ & $\begin{array}{l}\text { - Metakognityvinis stebejjimas; } \\
\text { - Metakognityvinè kontrolė; } \\
\text { - Metakognityvinè euristika. }\end{array}$ & $\begin{array}{l}\text { Kokybinis } \\
\text { tyrimas }\end{array}$ \\
\hline $\begin{array}{l}\text { Annevirta ir } \\
\text { Vauras, } 2006\end{array}$ & $6-7$ metai & Suomija & $\begin{array}{l}\text { Visa } \\
\text { apimantis } \\
\text { mokymasis }\end{array}$ & $\begin{array}{l}\text { - Suvokimo procesai; } \\
\text { - Motyvacija; } \\
\text { - Mokymosi pagalbos ieškojimas; } \\
\text { - Metakognityviniai igūdžiai. }\end{array}$ & $\begin{array}{l}\text { Kiekybinis } \\
\text { tyrimas }\end{array}$ \\
\hline $\begin{array}{l}\text { Akaydin ir kt., } \\
2020\end{array}$ & $\begin{array}{l}3 \text { ir } 4 \\
\text { klasès } \\
\text { mokiniai }\end{array}$ & Turkija & $\begin{array}{l}\text { Visa } \\
\text { apimantis } \\
\text { mokymasis }\end{array}$ & $\begin{array}{l}\text { - Metakognityvinis suvokimas; } \\
\text { - Savarankiškų sprendimų priè- } \\
\text { mimas. }\end{array}$ & $\begin{array}{l}\text { Kiekybinis } \\
\text { tyrimas }\end{array}$ \\
\hline $\begin{array}{l}\text { Marulis ir kt., } \\
2016\end{array}$ & $\begin{array}{l}3-5,5 \\
\text { metai }\end{array}$ & $\begin{array}{l}\text { Jungtinès } \\
\text { Amerikos } \\
\text { Valstijos }\end{array}$ & $\begin{array}{l}\text { Visa } \\
\text { apimantis } \\
\text { mokymasis }\end{array}$ & $\begin{array}{l}\text { - Metakognityvinès žinios; } \\
\text { - Metakognityviniai žinių procesai. }\end{array}$ & $\begin{array}{l}\text { Kokybinis } \\
\text { tyrimas }\end{array}$ \\
\hline $\begin{array}{l}\text { Zohar ir Barzilai, } \\
2013\end{array}$ & 5-9 metai & Izraelis & $\begin{array}{l}\text { Gamtos } \\
\text { mokslai }\end{array}$ & $\begin{array}{l}\text { - Metakognityvaus mokymo } \\
\text { praktikos; } \\
\text { - Metapažinimas ir mokytojų } \\
\text { kvalifikacijos kèlimas; } \\
\text { - Metakognityvus mąstymas. }\end{array}$ & $\begin{array}{l}\text { Kokybinis } \\
\text { tyrimas }\end{array}$ \\
\hline $\begin{array}{l}\text { Annevirta ir kt., } \\
2007\end{array}$ & 7-9 metai & Suomija & $\begin{array}{l}\text { Teksto } \\
\text { suvokimas }\end{array}$ & $\begin{array}{l}\text { - Metakognityvinès žinios; } \\
\text { - Klausymo ir rašymo užduočių } \\
\text { suvokimas. }\end{array}$ & $\begin{array}{l}\text { Kiekybinis } \\
\text { tyrimas }\end{array}$ \\
\hline $\begin{array}{l}\text { Erhel ir Jamet, } \\
2013\end{array}$ & $\begin{array}{l}6-10 \\
\text { metų }\end{array}$ & $\begin{array}{l}\text { Prancū- } \\
\text { zija }\end{array}$ & $\begin{array}{l}\text { Loginis } \\
\text { mąstymas }\end{array}$ & $\begin{array}{l}\text { - Mokymosi motyvaciją skatinan- } \\
\text { tys veiksniai; } \\
\text { - Skirtingų mokymosi metodų } \\
\text { taikymas. }\end{array}$ & $\begin{array}{l}\text { Kokybinis } \\
\text { tyrimas }\end{array}$ \\
\hline Spiess ir kt., 2015 & $6-9$ metai & Šveicarija & $\begin{array}{l}\text { Visa } \\
\text { apimantis } \\
\text { mokymasis }\end{array}$ & $\begin{array}{l}\text { - Atminties procesai mokymesi; } \\
\text { - Metakognityvinė kontrolè. }\end{array}$ & $\begin{array}{l}\text { Kiekybinis } \\
\text { tyrimas }\end{array}$ \\
\hline $\begin{array}{l}\text { Krebs ir Roebers, } \\
2010\end{array}$ & $8-9$ metai & Šveicarija & $\begin{array}{l}\text { Visa } \\
\text { apimantis } \\
\text { mokymasis }\end{array}$ & $\begin{array}{l}\text { - Metakognityvinis stebèjimas; } \\
\text { - Mokymosi kontrolès igūdžiai. }\end{array}$ & $\begin{array}{l}\text { Kiekybinis } \\
\text { tyrimas }\end{array}$ \\
\hline
\end{tabular}




\begin{tabular}{|c|c|c|c|c|c|}
\hline Autorius & $\begin{array}{l}\text { Tiriamujuc } \\
\text { amžius/ } \\
\text { klasė }\end{array}$ & Šalis & $\begin{array}{c}\text { Tyrimo } \\
\text { kontekstas }\end{array}$ & $\begin{array}{l}\text { Analizuojami metamokymosi } \\
\text { komponentai/aspektai }\end{array}$ & $\begin{array}{l}\text { Tyrimo } \\
\text { tipas }\end{array}$ \\
\hline $\begin{array}{l}\text { Destan ir Roebers, } \\
2015\end{array}$ & 6 metai & $\begin{array}{l}\text { Jungtinès } \\
\text { Amerikos } \\
\text { Valstijos }\end{array}$ & $\begin{array}{l}\text { Visa } \\
\text { apimantis } \\
\text { mokymasis }\end{array}$ & $\begin{array}{l}\text { - Metakognityvūs sprendimai; } \\
\text { - Metakognityvinè diskriminacija; } \\
\text { - Metakognityvinės kontrolès } \\
\text { kintamieji. }\end{array}$ & $\begin{array}{l}\text { Kiekybinis } \\
\text { tyrimas }\end{array}$ \\
\hline $\begin{array}{l}\text { Roebers ir kt., } \\
2012\end{array}$ & 6-7 metai & $\begin{array}{l}\text { Jungtinès } \\
\text { Amerikos } \\
\text { Valstijos }\end{array}$ & $\begin{array}{l}\text { Visa } \\
\text { apimantis } \\
\text { mokymasis }\end{array}$ & $\begin{array}{l}\text { - Metakognityvinis stebejimas ir } \\
\text { kontrolë; } \\
\text { - Savo mokymosi procesų suvo- } \\
\text { kimas. }\end{array}$ & $\begin{array}{l}\text { Kiekybinis } \\
\text { tyrimas }\end{array}$ \\
\hline $\begin{array}{l}\text { Bryce ir Whitebre- } \\
\text { ad, } 2012\end{array}$ & 5-7 metai & $\begin{array}{l}\text { Jungtinès } \\
\text { Amerikos } \\
\text { Valstijos }\end{array}$ & $\begin{array}{l}\text { Visa } \\
\text { apimantis } \\
\text { mokymasis }\end{array}$ & $\begin{array}{l}\text { - Metakognityviniai igūdžiai; } \\
\text { - Problemų sprendimo igūdžiai. }\end{array}$ & $\begin{array}{l}\text { Kiekybinis } \\
\text { tyrimas }\end{array}$ \\
\hline $\begin{array}{l}\text { Akturk ir Sahin, } \\
2011\end{array}$ & $\begin{array}{l}\text { Pradinès } \\
\text { mokyklos } \\
\text { mokiniai }\end{array}$ & Turkija & $\begin{array}{l}\text { Visa } \\
\text { apimantis } \\
\text { mokymasis }\end{array}$ & $\begin{array}{l}\text { - Metakognityvinès strategijos; } \\
\text { - Kognityvinès strategijos; } \\
\text { - Metakognicija kaip skètinis } \\
\text { terminas. }\end{array}$ & $\begin{array}{l}\text { Kokybinis } \\
\text { tyrimas }\end{array}$ \\
\hline $\begin{array}{l}\text { Kostons ir Werf, } \\
2015\end{array}$ & 6-9 metai & $\begin{array}{l}\text { Jungtinè } \\
\text { Karalystė }\end{array}$ & $\begin{array}{l}\text { Teksto } \\
\text { suvokimas }\end{array}$ & $\begin{array}{l}\text { - Metakognityvinių žinių aktyvi- } \\
\text { nimas. }\end{array}$ & $\begin{array}{l}\text { Kokybinis } \\
\text { tyrimas }\end{array}$ \\
\hline $\begin{array}{l}\text { Rhodes ir Well- } \\
\text { man, } 2012\end{array}$ & $3-4$ metai & $\begin{array}{l}\text { Jungtinès } \\
\text { Amerikos } \\
\text { Valstijos }\end{array}$ & $\begin{array}{l}\text { Visa } \\
\text { apimantis } \\
\text { mokymasis }\end{array}$ & $\begin{array}{l}\text { - Sprendimų prièmimas ir jų } \\
\text { kontrolė; } \\
\text { - Metamokymasis vaikysteje. }\end{array}$ & $\begin{array}{l}\text { Kokybinis } \\
\text { tyrimas }\end{array}$ \\
\hline Shamir ir kt., 2009 & $4-5$ metai & Izraelis & $\begin{array}{l}\text { Kalbų } \\
\text { mokymasis }\end{array}$ & $\begin{array}{l}\text { - Mažų vaikų metakognityvumo } \\
\text { vertinimas skirtinguose konteks- } \\
\text { tuose. }\end{array}$ & $\begin{array}{l}\text { Kokybinis } \\
\text { tyrimas }\end{array}$ \\
\hline $\begin{array}{l}\text { Marulis ir kt., } \\
2013\end{array}$ & $4-6$ metai & $\begin{array}{l}\text { Jungtinès } \\
\text { Amerikos } \\
\text { Valstijos }\end{array}$ & $\begin{array}{l}\text { Teksto } \\
\text { suvokimas }\end{array}$ & $\begin{array}{l}\text { - Mažų vaikų metakognityvinès } \\
\text { žinios; } \\
\text { - Ikimokykliniame amžiuje } \\
\text { patirtos mokymosi sèkmès įtaka } \\
\text { tolesniam mokymuisi. }\end{array}$ & $\begin{array}{l}\text { Kokybinis } \\
\text { tyrimas }\end{array}$ \\
\hline Zheng, 2017 & 10 metų & Kinija & $\begin{array}{l}\text { Kalbų } \\
\text { mokymasis }\end{array}$ & $\begin{array}{l}\text { - Metakognityvinès strategijos; } \\
\text { - Metakognityvinis suvokimas. }\end{array}$ & $\begin{array}{l}\text { Kokybinis } \\
\text { ir kiekybi- } \\
\text { nis tyrimas }\end{array}$ \\
\hline $\begin{array}{l}\text { McClelland ir } \\
\text { Cameron, } 2012\end{array}$ & $4-6$ metai & $\begin{array}{l}\text { Jungtinès } \\
\text { Amerikos } \\
\text { Valstijos }\end{array}$ & $\begin{array}{l}\text { Gamtos } \\
\text { mokslai }\end{array}$ & $\begin{array}{l}\text { - Mokymosi procesai ankstyvoje } \\
\text { vaikysteje; } \\
\text { - Savireguliacija. }\end{array}$ & $\begin{array}{l}\text { Kokybinis } \\
\text { tyrimas }\end{array}$ \\
\hline $\begin{array}{l}\text { Suminto ir Mbato, } \\
2020\end{array}$ & $5-6$ metai & $\begin{array}{l}\text { Indone- } \\
\text { zija }\end{array}$ & $\begin{array}{l}\text { Visa } \\
\text { apimantis } \\
\text { mokymasis }\end{array}$ & $\begin{array}{l}\text { - Pažinimo reguliavimo žinios; } \\
\text { - Pradinio ugdymo iššukiai. }\end{array}$ & $\begin{array}{l}\text { Kokybinis } \\
\text { ir kiekybi- } \\
\text { nis tyrimas }\end{array}$ \\
\hline
\end{tabular}




\begin{tabular}{|c|c|c|c|c|c|}
\hline Autorius & $\begin{array}{l}\text { Tiriamujuc } \\
\text { amžius/ } \\
\text { klasė }\end{array}$ & Šalis & $\begin{array}{c}\text { Tyrimo } \\
\text { kontekstas }\end{array}$ & $\begin{array}{l}\text { Analizuojami metamokymosi } \\
\text { komponentai/aspektai }\end{array}$ & $\begin{array}{l}\text { Tyrimo } \\
\text { tipas }\end{array}$ \\
\hline Stonkuvienè, 2018 & $4-6$ metai & Lietuva & $\begin{array}{l}\text { Ikimo- } \\
\text { kyklinis } \\
\text { ugdymas }\end{array}$ & $\begin{array}{l}\text { - Mokejjimo mokytis planavimas } \\
\text { ikimokyklinio ugdymo ịstaigų } \\
\text { programose; } \\
\text { - Mokèjimo mokytis problemišku- } \\
\text { mas ir iššūkiai; } \\
\text { - Metakognityviniai gebejiimai. }\end{array}$ & $\begin{array}{l}\text { Kokybinis } \\
\text { tyrimas }\end{array}$ \\
\hline $\begin{array}{l}\text { Bryce ir Whitebread, } \\
2014\end{array}$ & 5-7 metai & $\begin{array}{l}\text { Jungtinès } \\
\text { Amerikos } \\
\text { Valstijos }\end{array}$ & $\begin{array}{l}\text { Matemati- } \\
\text { nis raštin- } \\
\text { gumas }\end{array}$ & $\begin{array}{l}\text { - Metakognityviniai igūdžiai; } \\
\text { - Mokymosi igūdžių kontrolè; } \\
\text { - Darbinė atmintis; } \\
\text { - Metamokymosi pasiekimai. }\end{array}$ & $\begin{array}{l}\text { Kiekybinis } \\
\text { tyrimas }\end{array}$ \\
\hline$\frac{\text { Mansueto ir kt., }}{2019}$ & $\begin{array}{l}\text { Pradinès } \\
\text { mokyklos } \\
\text { mokiniai }\end{array}$ & Italija & $\begin{array}{l}\text { Visa } \\
\text { apimantis } \\
\text { mokymasis }\end{array}$ & $\begin{array}{l}\text { - Metakognityvūs įsitikinimai ir } \\
\text { vaikystės sunkumai. }\end{array}$ & $\begin{array}{l}\text { Kokybinis } \\
\text { tyrimas }\end{array}$ \\
\hline $\begin{array}{l}\text { Caliskan ir } \\
\text { Sunbul, } 2011\end{array}$ & $\begin{array}{l}\text { Pradinès } \\
\text { mokyklos } \\
\text { mokiniai }\end{array}$ & Turkija & $\begin{array}{l}\text { Visa } \\
\text { apimantis } \\
\text { mokymasis }\end{array}$ & $\begin{array}{l}\text { - Mokymosi strategijos; } \\
\text { - Metakognityvinès žinios; } \\
\text { - Metakognityviniai igūdžiai. }\end{array}$ & $\begin{array}{l}\text { Kokybinis } \\
\text { tyrimas }\end{array}$ \\
\hline $\begin{array}{l}\text { Schneider ir } \\
\text { Artelt, } 2010\end{array}$ & $\begin{array}{l}\text { Pradinès } \\
\text { mokyklos } \\
\text { mokiniai }\end{array}$ & Vokietija & $\begin{array}{l}\text { Matemati- } \\
\text { nis raštin- } \\
\text { gumas }\end{array}$ & $\begin{array}{l}\text { - Mokymesi patirta sèkmè ir kryp- } \\
\text { tingas ugdymas; } \\
\text { - Metakognityvinès žinios. }\end{array}$ & $\begin{array}{l}\text { Kokybinis } \\
\text { tyrimas }\end{array}$ \\
\hline
\end{tabular}

Siekiant optimizuoti mokymąsi, skirtinguose kontekstuose atliktuose metamokymosi tyrimuose antroje lentelëje pakartotinai išskiriami pasikartojantys savarankiško mokymosi komponentai: metakognityvinès žinios, nuolatinis metakognityvinių igūdžių tobulinimas, mąstymas apie savo mąstymą, mokymosi reguliavimas, mokymosi problemų sprendimų paieškos, gebejjimas tiksliai ir kryptingai ieškoti reikiamos pagalbos, savo mokymosi vertinimas. Mokymąsi apie tai, kaip mokomasi, kai kurie autoriai vadina metamokymusi ir apibrèžia mokymąsi kaip žinių kūrimo procesą. Daugelyje tyrimų akcentuojama, kad mokèjimo mokytis centre yra savęs, kaip besimokančiojo, suvokimas, siekiant prasmingo ir sąmoningo mokymosi proceso. Taip pat pastebima, kad spręsdami kylančias mokymosi problemas savarankiški besimokantieji strategiškiau nei iprasti besimokantieji kreipiasi informacijos ir pagalbos ị mokytojus, o jų klausimai dažniau apsiriboja tik tuo, kas būtina, ir yra konkretesni (Cornoldi ir kt., 2015; Mansueto ir kt., 2019; Akaydin ir kt., 2020). Būtina skatinti besimokantijji suvokti ir prisiimti atsakomybę už savo mokymąsi, nes tai svarbu tolesnei mokymosi sèkmei ịvairiose mokymosi aplinkose (Roberts, 2010). Zhengas (2017) tyrẻ kritinio mąstymo svarbą, pabrèždamas, kad tai yra mokejjimo mokytis pagrindas, apimantis daugybę skirtingų gebejjimų, kurie yra svarbūs besimokančiajam ịvairiose jo gyvenimo aplinkose. Mokslininkai (Caliskan ir Sunbul, 2011; Marulis ir kt., 2013; Suminto ir Mbato, 2020) akcentuoja tokias būtinas besimokančiųjų nuostatas: motyvaciją mokytis savarankiškai, pozityvų nusiteikimą mokytis, pasitikejimą, refleksiją. Kostons ir Werf (2015) teigia, kad mokejjimo mokytis 
kompetencija apima įvairias kognityvines ir emocines sritis: mokejjimą mąstyti, mokymosi strategijas, metakogniciją, pasitikejimą savimi ir motyvaciją. Vienu svarbiausių laikomas mokejimo mokytis gebëjimas, o iš jo kylantis pasitikèjimas savimi ir motyvacija mokytis yra būtina ir esminè prielaida, susijusi su prasmingu ir sąmoningu mokymosi procesu. Pasikliaudami savo mąstymu ir mokymosi stebejjimu, vaikai ịvardija prièmę teisingą arba neteisingą sprendimą. Nuolat priimdami tik neteisingus sprendimus, vaikai nebepasitiki savo mokymusi, o mokymo metodus, kurių nesupranta, yra linkę laikyti neprasmingais (Bares, 2011).

Metamokymosi igyvendinimo praktikos pradiniame ugdyme. Remdamiesi atliktų tyrimų duomenimis, darome prielaidą, kad vaikai nuolat stengiasi stebèti ir vertinti savo mokymąsi, pastebėti klaidas ir jas kontroliuoti, o išgyventa mokymosi sẻkmè naudojant metamokymosi strategijas didina net ir mažiau motyvuotų mokinių motyvaciją mokytis. Mokslinių analizių metu pakartotinai akcentuojama, kad sèkmingai savo mokymąsi valdantys, ji suvokiantys ir strategiškai besimokantys vaikai, nepriklausomai nuo aplink esančiu mažiau motyvuotų bendraklasių, geba išlaikyti motyvaciją mokytis ir siekti išsikeltų mokymosi tikslų.

Flavellas ir kt. (2002) išskiria du pagrindinius metamokymosi komponentus: metakognityvines žinias ir metakognityvinę stebėseną bei jos savireguliaciją. Metakognityvinès žinios nurodo žinias, ịsitikinimus, idejjas ir teorijas apie žmones, kaip „kognityvines būtybes“, apie skirtingą jų sąveiką su kognityvinèmis užduotimis bei mokymosi strategijomis (Flavell, 1979) ir yra skirstomos ị tris pogrupius: žinias apie asmenis, užduotis ir strategijas. Žinios apie asmenis apima savo paties kintamųjų, kurie daro įtaką jų pažintinei veiklai, pažinimą. Žinios apie užduotis apibrèžia, kaip užduočių sąlygų, reikalavimų ir tikslų pobūdis veikia besimokančiųjų pažintinę veiklą. Mokymosi strategijų išmanymas leidžia valdyti turimas žinias apie mąstymo, mokymosi ir problemų sprendimo strategijas, kurias besimokantieji gali naudoti siekdami išsikeltų ugdymosi tikslų.

Vadovaujantis atliktais tyrimais ir metamokymosi struktūra, straipsnyje analizuotų metamokymosi praktikos igyvendinimo patirčių rezultatai pateikiami 3 lentelèje. Analizuotų tyrimų metu atskleista, kad metamokymasis yra dinamiškas procesas, vykstantis skirtingų socialinių ir švietimo kontekstų įvairoveje. Vaikų metapažinimas didejja su amžiumi ir sẻkmingai gali būti vystomas jau pradinèje mokykloje, o „metakognityvinių ịgūdžių nesèkmèms“ pirmiausia turi ịtakos konkretus uždavinys, o ne amžius (Nieto-Márquez et al., 2020; Larkin, 2010; Schneider, 2008). Neuenhaus et al. (2011) tyrimai rodo, kad metamokymosi stebẻjimas ir kontrolè yra akivaizdūs jau ikimokyklinio amžiaus vaikų elgesyje ir nuolat vystosi pradinio ugdymo proceso metu. Sim ir Xu (2017) pabrèžia, kad vaikai tyrinejja neatsitiktinai - jie mokosi ir laisvai žaisdami, taip pat gali sugeneruoti susijusius įrodymus ir suformuoti deramus aukštesnio lygio apibendrinimus. Vaikai žaidžia spontaniškai tyrinėdami, kas iš tiesų gali būti motyvuota jų troškimų suprasti, kokios priežastys daro ịtaką kitų objektų, esančių aplink juos, elgesiui. Kartu tai leidžia vystytis didesnėms konceptualioms struktūroms, kurios valdo prognozes ir paaiškinimus. 


\section{3 lentelè}

Metamokymosi igyvendinimo praktikos pradiniame ugdyme

\begin{tabular}{|c|c|c|c|c|}
\hline $\begin{array}{l}\text { Meta- } \\
\text { kogni- } \\
\text { tyviniai } \\
\text { kompo- } \\
\text { nentai }\end{array}$ & $\begin{array}{l}\text { Metako- } \\
\text { gnityvinių } \\
\text { komponen- } \\
\text { tų bruožai }\end{array}$ & $\begin{array}{l}\text { Praktikoje taikomo meta- } \\
\text { mokymosi bruožai }\end{array}$ & $\begin{array}{c}\text { Kylantys metamokymosi } \\
\text { iššūkiai ir galimybès } \\
\text { pradinio ugdymo } \\
\text { mokiniams }\end{array}$ & Autorius \\
\hline & $\begin{array}{l}\text { Žinios } \\
\text { apie save, } \\
\text { kaip besi- } \\
\text { mokantijit }\end{array}$ & $\begin{array}{l}\text { - Keliami asmeniniai mo- } \\
\text { kymosi tikslai; } \\
\text { - Vidinė motyvacija pa- } \\
\text { siekti užsibrèžtą tikslą; } \\
\text { - Vidinè motyvacija ieško- } \\
\text { ti ir bandyti kitaip spręsti } \\
\text { mokymosi problemą; } \\
\text { - Pasitikejjimas savo priim- } \\
\text { tais sprendimais vadovau- } \\
\text { jantis igytomis žiniomis. }\end{array}$ & $\begin{array}{l}\text { - Žinios apie savo mokymąsi } \\
\text { jaunesniame amžiuje vis dar } \\
\text { yra gana ribotos, o metamo- } \\
\text { kymosi koncepto aiškumo } \\
\text { trūkumas apsunkina atlieka- } \\
\text { mus tyrimus; } \\
\text { - Sėkmingas mokymosi pro- } \\
\text { cesas neįmanomas su skir- } \\
\text { tingomis to paties mokymosi } \\
\text { sampratomis; } \\
\text { - Neapibrěžti mokymosi me- } \\
\text { todai, suvokimo trūkumas } \\
\text { apie savianalizès ir refleksijos } \\
\text { metodus (Rhodes ir Well- } \\
\text { man, 2012). }\end{array}$ & $\begin{array}{l}\text { Marulis ir } \\
\text { kt., 2016; } \\
\text { Zohar ir } \\
\text { Barzilai, } \\
\text { 2013; } \\
\text { Annevirta ir } \\
\text { kt., 2007; } \\
\text { Spiess ir kt., } \\
\text { 2015. }\end{array}$ \\
\hline $\begin{array}{l}\text { Meta- } \\
\text { kogni- } \\
\text { tyvinès } \\
\text { žinios }\end{array}$ & $\begin{array}{l}\text { Pažinimo } \\
\text { suvokimas } \\
\text { ir valdy- } \\
\text { mas }\end{array}$ & $\begin{array}{l}\text { - Tos pačios veiklos kar- } \\
\text { tojimas taikant skirtingus } \\
\text { mokymosi metodus; } \\
\text { - Gebèjimas atskirti svar- } \\
\text { bią ir nesusijusią infor- } \\
\text { maciją; } \\
\text { - Mokymosi proceso kon- } \\
\text { trolė; } \\
\text { - Suvokiamos mokymosi } \\
\text { galimybės ir stengiamasi } \\
\text { ieškoti skirtingų moky- } \\
\text { mosi būdų; } \\
\text { - Eksperimentuojama, } \\
\text { stebima ir reguliuojamas } \\
\text { užduoties atlikimas; }\end{array}$ & $\begin{array}{l}\text { - Pedagogų kompetencijos } \\
\text { stoka; } \\
\text { - Besimokantieji nepasitiki } \\
\text { savo mokymusi, o mokymo } \\
\text { metodus, kurių nesupranta, } \\
\text { yra linkę laikyti neprasmin- } \\
\text { gais; } \\
\text { - Metakognotyvinių stra- } \\
\text { tegijų naudojimas didina } \\
\text { mažiau motyvuotų mokinių } \\
\text { motyvaciją mokytis; } \\
\text { - Pagerëjusi metakognityvinè } \\
\text { atmintis leidžia veiksmingiau } \\
\text { spręsti mokymosi problemas; } \\
\text { - Ankstyvame amžiuje savo } \\
\text { mokymosi igūdžių suvoki- } \\
\text { mas daro ịtaką metakogni- } \\
\text { tyvinių kontrolès igūdžių } \\
\text { ugdymui. }\end{array}$ & $\begin{array}{l}\text { Nieto- } \\
\text { Márquez ir } \\
\text { kt., 2020; } \\
\text { Cornoldi ir } \\
\text { kt., 2015; } \\
\text { Baas ir kt., } \\
\text { 2015; } \\
\text { Bares, 2011; } \\
\text { Geurten, } \\
\text { 2016; } \\
\text { Krebs ir Ro- } \\
\text { ebers, 2010; } \\
\text { Shamir ir } \\
\text { kt., 2009; } \\
\text { McClelland } \\
\text { ir Cameron, } \\
\text { 2012. }\end{array}$ \\
\hline
\end{tabular}




\begin{tabular}{|c|c|c|c|c|}
\hline $\begin{array}{l}\text { Meta- } \\
\text { kogni- } \\
\text { tyviniai } \\
\text { kompo- } \\
\text { nentai }\end{array}$ & $\begin{array}{l}\text { Metako- } \\
\text { gnityvinių } \\
\text { komponen- } \\
\text { tų bruožai }\end{array}$ & $\begin{array}{l}\text { Praktikoje taikomo meta- } \\
\text { mokymosi bruožai }\end{array}$ & $\begin{array}{c}\text { Kylantys metamokymosi } \\
\text { iššūkiai ir galimybès } \\
\text { pradinio ugdymo } \\
\text { mokiniams }\end{array}$ & Autorius \\
\hline & $\begin{array}{l}\text { Žinios, ko- } \\
\text { dèl ir kada } \\
\text { naudoti } \\
\text { strategiją }\end{array}$ & $\begin{array}{l}\text { - Diskutuoja apie pasi- } \\
\text { rinktus mokymosi me- } \\
\text { todus; } \\
\text { - Gebama vadovautis me- } \\
\text { todų paieška ir kritiškai } \\
\text { vertinti, atsirinkti, kas } \\
\text { suvokiama ir gali būti } \\
\text { taikoma; } \\
\text { - Priima savarankiškus } \\
\text { sprendimus dėl savo mo- } \\
\text { kymosi metodų; } \\
\text { - Žino galimus mokymosi } \\
\text { metodus, jais naudojasi ir } \\
\text { reguliuoja mokymąsi; } \\
\text { - Taiko skirtingus mo- } \\
\text { kymosi metodus, siekia } \\
\text { spręsti mokymosi pro- } \\
\text { blemas. }\end{array}$ & $\begin{array}{l}\text { - Mokymosi metodų ivvairovė } \\
\text { motyvuoja vaikus mokytis; } \\
\text { - Siekiant sėkmingai plètoti } \\
\text { metakognityvų mokymą, } \\
\text { mokytojams būtina pateikti } \\
\text { konceptualizuotas metako- } \\
\text { gnityvaus mokymo strategijų } \\
\text { žinias; } \\
\text { - Žinių trūkumas ir negebèji- } \\
\text { mas sukonkretinti jų paieškos } \\
\text { procesų daro neigiamą įtaką } \\
\text { strateginio reguliavimo igū- } \\
\text { džiams. }\end{array}$ & $\begin{array}{l}\text { Nelson ir } \\
\text { Fyfe, 2019; } \\
\text { Bonnett ir } \\
\text { kt., 2017; } \\
\text { Cornoldi ir } \\
\text { kt., 2015; } \\
\text { Zohar ir } \\
\text { Barzilai, } \\
\text { 2013; } \\
\text { Roebers ir } \\
\text { kt., 2012; } \\
\text { Marulis ir } \\
\text { kt., 2013; } \\
\text { McClelland } \\
\text { ir Cameron, } \\
\text { 2012. }\end{array}$ \\
\hline & $\begin{array}{l}\text { Tinkamų } \\
\text { strategijų } \\
\text { nustaty- } \\
\text { mas ir pa- } \\
\text { rinkimas }\end{array}$ & $\begin{array}{l}\text { - Apmąsto savo mokymo- } \\
\text { si planą; } \\
\text { - Sudaro savo mokymosi } \\
\text { planą. } \\
\text { - Išsikelia mokymosi tiks- } \\
\text { lus, numato mokymosi } \\
\text { metodus; } \\
\text { - Nuolat ieško skirtingų } \\
\text { metodų mokymosi gebé- } \\
\text { jimų tobulinimui; } \\
\text { - Suvokia mokymosi pro- } \\
\text { cesą, siekia ji tobulinti. }\end{array}$ & $\begin{array}{l}\text { - Nepakankama pedagogų } \\
\text { kompetencija taikyti meta- } \\
\text { mokymosi strategijas anksty- } \\
\text { vame ugdyme daro neigiamą } \\
\text { ittaką vaikų mokymosi ịpročių } \\
\text { formavimui ir mąstymui apie } \\
\text { mokymąsi. } \\
\text { - Susijusių kognityvinių gebė- } \\
\text { jimų: perspektyvinės atmin- } \\
\text { ties, vykdomųų funkcijų ir } \\
\text { metakognityvumo taikymas, } \\
\text { pradinių klasių mokiniams } \\
\text { atveria naujas mokymosi ga- } \\
\text { limybes ir didina mokymosi } \\
\text { motyvaciją. }\end{array}$ & $\begin{array}{l}\text { Geurten, } \\
\text { 2016; } \\
\text { Annevirta } \\
\text { ir Vauras, } \\
\text { 2006; } \\
\text { Akaydin ir } \\
\text { kt., 2020; } \\
\text { Zohar ir } \\
\text { Barzilai, } \\
\text { 2013; } \\
\text { Spiess ir kt., } \\
\text { 2015; } \\
\text { Marulis ir } \\
\text { kt., 2013. }\end{array}$ \\
\hline
\end{tabular}




\begin{tabular}{|c|c|c|c|c|}
\hline $\begin{array}{c}\text { Meta- } \\
\text { kogni- } \\
\text { tyviniai } \\
\text { kompo- } \\
\text { nentai }\end{array}$ & $\begin{array}{l}\text { Metako- } \\
\text { gnityvinių } \\
\text { komponen- } \\
\text { tų bruožai }\end{array}$ & $\begin{array}{l}\text { Praktikoje taikomo meta- } \\
\text { mokymosi bruožai }\end{array}$ & $\begin{array}{c}\text { Kylantys metamokymosi } \\
\text { iššūkiai ir galimybès } \\
\text { pradinio ugdymo } \\
\text { mokiniams }\end{array}$ & Autorius \\
\hline $\begin{array}{l}\text { Meta } \\
\text { regulia- } \\
\text { vimas }\end{array}$ & $\begin{array}{l}\text { Suprati- } \\
\text { mas ir su- } \\
\text { vokiamas } \\
\text { užduočių } \\
\text { atlikimas }\end{array}$ & $\begin{array}{l}\text { - Prisiima atsakomybę už } \\
\text { savo mokymąsi; } \\
\text { - Vykdo nuolatinę reflek- } \\
\text { siją viso mokymosi metu; } \\
\text { - Vadovaujasi lanksčiu } \\
\text { mokymosi planu, atitin- } \\
\text { kančiu besikeičiančius } \\
\text { poreikius; } \\
\text { - Aktyviai dalyvauja mo- } \\
\text { kymosi procese; } \\
\text { - Siekia geriau suvokti } \\
\text { naujas ir turimas žinias, } \\
\text { tam taiko skirtingus me- } \\
\text { todus, (Kostons and Werf, } \\
\text { 2015). }\end{array}$ & $\begin{array}{l}\text { - Pastebi savo klaidas, jas } \\
\text { kontroliuoja ir taip didina } \\
\text { pasitikejjimą savo jègomis; } \\
\text { - Vidinė mokinių motyvacija } \\
\text { ir klasės mokymosi pro- } \\
\text { ceso valdymas, trūkstant } \\
\text { konkrečių metamokymosi } \\
\text { vertinimo ir standartizavimo } \\
\text { apibrěžčių, pedagogams tam- } \\
\text { pa vis didesniu iššūkiu. } \\
\text { - Pedagogai turi igyti papil- } \\
\text { domų igūdžių, kad gebėtų } \\
\text { efektyviai igyvendinti meta- } \\
\text { mokymąsi ugdymo procese; } \\
\text { - Pradinių klasių mokiniai } \\
\text { geba kontroliuoti ir nukreipti } \\
\text { savo psichinius procesus bei } \\
\text { žinomas strategijas i̇ esamas } \\
\text { situacijas mokymosi metu. } \\
\text { - İvardytos sąsajos ir veiks- } \\
\text { niai, darantys itaką mokymo- } \\
\text { si igūdžių augimui ir plètotei. } \\
\text { - Metamokymasis padeda be- } \\
\text { simokantiesiems atskirti len- } \\
\text { gvus, sunkius ir neatsakomus } \\
\text { dalykus bei argumentuotai } \\
\text { pateikti teisingus ir neteisin- } \\
\text { gus atsakymus. } \\
\text { - Pervertinti savo mokymosi } \\
\text { tgūdžiai lemia mokymosi lè- } \\
\text { tėjimą ir galiausiai mokymosi } \\
\text { regresą (Destan ir Roebers, } \\
\text { 2015). }\end{array}$ & $\begin{array}{l}\text { Nelson ir } \\
\text { Fyfe, 2019; } \\
\text { Bonnett ir } \\
\text { kt., 2017; } \\
\text { Rieser ir kt., } \\
\text { 2016; } \\
\text { Baas ir kt., } \\
\text { 2015; } \\
\text { Bares, 2011; } \\
\text { Akaydin ir } \\
\text { kt., 2020; } \\
\text { Annevirta ir } \\
\text { kt., 2007; } \\
\text { Krebs ir } \\
\text { Roebers, } \\
\text { 2010; } \\
\text { Bryce ir } \\
\text { Whitebread, } \\
\text { 2012; } \\
\text { Shamir ir } \\
\text { kt., 2009; } \\
\text { Zheng, 2017; } \\
\text { Stonkuviené, } \\
\text { 2018; } \\
\text { Monkevi- } \\
\text { čienè ir kt. } \\
\text { 2020. }\end{array}$ \\
\hline
\end{tabular}




\begin{tabular}{|c|c|c|c|c|}
\hline $\begin{array}{l}\text { Meta- } \\
\text { kogni- } \\
\text { tyviniai } \\
\text { kompo- } \\
\text { nentai }\end{array}$ & $\begin{array}{l}\text { Metako- } \\
\text { gnityvinių } \\
\text { komponen- } \\
\text { tų bruožai }\end{array}$ & $\begin{array}{c}\text { Praktikoje taikomo meta- } \\
\text { mokymosi bruožai }\end{array}$ & $\begin{array}{c}\text { Kylantys metamokymosi } \\
\text { iššūkiai ir galimybès } \\
\text { pradinio ugdymo } \\
\text { mokiniams }\end{array}$ & Autorius \\
\hline & $\begin{array}{l}\text { Mokymosi } \\
\text { procesų } \\
\text { peržiū- } \\
\text { rèjimas, } \\
\text { vertinimas } \\
\text { ir tobulini- } \\
\text { mas }\end{array}$ & $\begin{array}{l}\text { - Refleksija. } \\
\text { - Mokymosi įsivertinimas; } \\
\text { - Vertinamas savo mo- } \\
\text { kymasis ir labiau savimi } \\
\text { pasitikima. }\end{array}$ & $\begin{array}{l}\text { - Vaikams, kurių pradinis } \\
\text { metakognityvinių žinių ly- } \\
\text { gis buvo aukštas, problemų } \\
\text { sprendimo būdai per pir- } \\
\text { muosius mokslo metus buvo } \\
\text { geresni, o vaikų, turinčių } \\
\text { žemesnį žinių lygit, elgesys la- } \\
\text { biau priminė nuo suaugusių- } \\
\text { jų priklausomą elgesio tipą, } \\
\text { būdingą mažiems vaikams. } \\
\text { - Aukštas pradinių klasių } \\
\text { mokinių metakognityvinis } \\
\text { supratimas daro ittaką jų aka- } \\
\text { deminiams pasiekimams ir } \\
\text { socialinių igūdžių formavi- } \\
\text { muisi (Young ir Fry, 2008; } \\
\text { (Gul ir Shehzad, 2012; Ugraş, } \\
\text { 2018). } \\
\text { - Mokymosi veikloje žiniomis } \\
\text { paremtas planavimas su nuo- } \\
\text { latiniu grižtamuoju ryšiu apie } \\
\text { mokymosi patirti suteikia } \\
\text { pasitikejjimo savimi ir didina } \\
\text { mokymosi motyvaciją (Erhel } \\
\text { ir Jamet, 2013). } \\
\text { - Neatsiejamai nuo amžiaus } \\
\text { metakognityvinis elgesys } \\
\text { kinta ir tobulëja. }\end{array}$ & $\begin{array}{l}\text { Nelson ir } \\
\text { Fyfe, 2019; } \\
\text { Bonnett ir } \\
\text { kt., 2017; } \\
\text { Nie- } \\
\text { to-Márquez } \\
\text { ir kt., 2020; } \\
\text { Rieser ir kt., } \\
\text { 2016; } \\
\text { Cornoldi ir } \\
\text { kt., 2015; } \\
\text { Annevirta } \\
\text { ir Vauras, } \\
\text { 2006; } \\
\text { Akaydin ir } \\
\text { kt., 2020; } \\
\text { Destan ir } \\
\text { Roebers, } \\
\text { 2015; } \\
\text { Bryce ir } \\
\text { Whitebread, } \\
\text { 2012; } \\
\text { Shamir ir } \\
\text { kt., 2009; } \\
\text { Zheng, 2017; } \\
\text { Stonkuviené, } \\
\text { 2018. }\end{array}$ \\
\hline
\end{tabular}

Schneider (2008) akcentuoja sèkmingas mokomąsias intervencijas, skatinančias besimokančiųjų pažinimą nuo 7-8 metų amžiaus. Remiantis tyrimų duomenimis, mokinių nukreipimas ị metakognityvinių gebejjimų, kurie apima motyvuotą savo paties mokymąsi reguliuojančią mokymosi veiklą jau pradiniame ugdyme, daro įtaką sąmoningam ir visą gyvenimą trunkančiam mokymosi procesui (Baas ir kt., 2015). Jau pradiniame ugdyme dèl sparčiai augančio informacijos ir žinių kiekio, kurị besimokantieji turi gebėti suprasti, kritiškai vertinti, atrinkti ir integruoti i jau turimas žinias taip, kad jos galètu būti pritaikytos kuriant naujas prasmes, remiantis tik kognityviais gebejjimais, 
tampa vis sudètingiau. Pradinėse klasėse metakognityvinès žinios padeda ugdyti vaikų gebejjimą suprasti save kaip besimokančiuosius: suprasti, kaip mokosi, žinoti etapus ir veiksmus, kuriuos jie atlieka mokymosi proceso metu, kad pasiektų nusimatytus mokymosi rezultatus (Tarrant air Holt, 2016), pavyzdžiui: kiek informacijos turiu apie mokomąjį dalyką, kiek laiko gali užtrukti, kol išmoksiu šį dalyką, kokio būdo turèčiau laikytis, kad galèčiau efektyviai mokytis, kaip turéčiau rasti savo klaidą ir ją ištaisyti, kodèl padariau klaidą ir kaip turečiau iš naujo pakoreguoti planą, kai jis nèra tinkamas. Atsakydamas $\mathfrak{i}$ tokius klausimus, besimokantysis ne tik pasitelkia jau turimas žinias, mąsto apie pasirinktas mokymosi strategijas, bet ir naudojasi savo sprendimų prièmimo igūdžiais, vertina savo mokymąsi.

Labiausiai mokslininkų tiriamas metakognityvinių žinių tipas yra savo mokymosi stebèjimas ir vertinimas, jo progresas. Mokslinejje literatūroje daugiausia dèmesio skiriama metamokymosi rezultatų prognozavimui, mokymosi proceso palengvinimui, mokymosi ir mąstymo apie savo mąstymą sprendimams (Akaydin ir kt., 2020). Daugumoje šių tyrimų pabrezžiama, kad šiuolaikinè didaktika, nepaneigdama visų klasikinès didaktikos teiginių, kelia naujus mokymosi reikalavimus jau pradinio ugdymo procese (Geurten, 2016; Nelson ir Fyfe, 2019; Bonnett ir kt., 2017; Cornoldi ir kt., 2015). Sutartinai pripažizstama, kad besimokantieji turi žinoti ir gebeti suvokti bei valdyti ịvairius mokymosi būdus, kuriais gali reguliuoti savo pažinimo procesus (Nelson ir Fyfe, 2019; Bonnett ir kt., 2017; Cornoldi ir kt., 2015), o metamokymasis tampa neatsiejama tokio mokymosi dalimi (Nieto-Márquez ir kt., 2020; Rieser ir kt., 2016). Mokymosi centre, pasak Frenkel (2014), yra metakognityviniai gebejimai, kurie padeda besimokančiajam sąmoningai ir palaipsniui suvokti, kaip jis mokosi ir kaip jam lengviausia mokytis, t. y. supranta pati mokymosi procesą. Vis daugiau tyrimų atliekama siekiant ištirti metamokymosi sąsajas, kai pagrindinis dėmesys skiriamas kitiems konstruktams, tokiems kaip probleminis mokymasis, mokymasis bendradarbiaujant, kuriuose metakognityvumas nurodomas kaip vienas iš aspektų, sèkmingai plètojančių mokymąsi skirtinguose kontekstuose (Bryce ir kt., 2015). Visuotinai sutariama, kad vienas iš būdų, kaip tèvai ir mokytojai gali palengvinti kognityvinę raidą, yra vaikų metapažinimo plètra (Coffman ir kt., 2008). Naujausi šio klausimo tyrimai rodo, kad šie tyrimai dar tik plètojami, tačiau galima pastebèti nemažą pažangą. Besimokantieji, turintys metakognityvinių igūdžių, gali stebèti savo mokymąsi, reikšti nuomonę apie informaciją, siekia atnaujinti žinias, kuria bei igyvendina naujas mokymosi strategijas, geriau žino savo stipriąsias ir silpnąsias puses, todèl nuolat stengiasi tobulinti savo mokymosi igūdžius.

Metakognityvinis suvokimas - svarbus terminas Lietuvos ir Europos švietimo platformose; jis būtinas mąstymo gebejimams ir gali būti sèkmingai skatinimas jau pradinio ugdymo lygmenyje, tačiau tam ypač svarbus mokytojo vaidmuo (Dignath ir Büttner, 2008). Vykstantys pokyčiai švietime ir visuomenejje kartu keičia ir patị mokytoją bei tradicinius mokytojo vaidmenis. Ilgą laiką visuomenẻje mokytojas dominavo kaip informacijos ir žinių šaltinis, o šiandien mokytojas užima mokymo(si) organizatoriaus, 
konsultanto, patarèjo, tarpininko, ugdymo proceso skatintojo ir kt. vaidmenis. Plačiai paplitusi prielaida, kad, norėdami tinkamai suprasti ir stiprinti besimokančiųjų savarankiškumą bei kūrybiškumą, skatinti jų ugdymą, mokytojai patys turètų būti kūrybingi nuolat besimokantys (Abedinin and Broujeni, 2016; Nieto-Marquez ir kt., 2020; Akaydin ir kt., 2020). Taigi, pradinių klasių mokinių metamokymasis ir jų sėkmingo savarankiško mokymosi igūdžių formavimas yra neatsiejama mokytojų kompetencijų ugdymo šioje srityje dalis. Vis delto Ispanijos (Nieto-Marquez ir kt., 2020), Vokietijos (Rieser ir kt., 2016), Italijos (Cornoldi ir kt., 2015), Belgijos (Geurten, 2016) ir kt. šalių mokslininkai vieningai pabrèžia, kad mokytojų skatinimas ir metakognityvių kompetencijų ugdymo mokymas yra kosmopolitine problema, kurios pagrindinès priežastys įvardijamos kaip trūkstamas metamokymosi konceptualumas ir politinių dokumentų orientavimas. Pasak Mylona (2016), empirinių metamokymosi tyrimų silpnumas ir stoka yra pasekmé, kad šiuo metu egzistuojančioms sistemoms buvo skiriama mažai dèmesio aiškiai apibrèžti visas konstrukcijas, kurios aktyviau ịtrauktų ị metamokymąsi ir padètų greičiau ịveikti kylančias mokymosi problemas mokiniams bei suteiktų naujų, i̇ metakognityvų mokymą orientuotų kompetencijų mokytojams.

Analizuojant mokslinius tyrimus, literatūrą pastebimas ir sąvokų metakognityvus mokymasis, savarankiškas mokymasis, savivaldus mokymasis, savireguliacinis mokymasis, savimoka, mokymasis mokytis ir mokejimas mokytis tapatumo bei apibrežties problemiškumas. Tyrèjai priskiria šiai sąvokai savo suvokimą, o dèl vertimų iš užsienio kalbų bei aplinkos pokyčių atsiranda vis daugiau šios sąvokos papildymų ir išplètimų, - tai dar labiau apsunkina šio mokymosi tyrimus ir konceptualizavimą.

\section{Išvados}

Pradinio ugdymo metu individualūs besimokančiųjų skirtumai ir bendri kontekstiniai mokymosi veiksniai sąveikauja su įvairiais metamokymosi komponentais ir yra analizuojami kokybiniais ir kiekybiniais tyrimais. Tyrimų rezultatuose tyrejai ịvardija ne tik šių metodų taikymo privalumus, bet išskiria ir ribotumus.

- Kokybiniuose tyrimuose remiamasi pamokų vaizdo ịrašais, klausimynais, interviu, mokslinès literatūros ir strateginių dokumentų analize. Atliekant interviu dažniausiai susiduriama su laiko trūkumu, o interpretuojant yra galimybè iškraipyti respondento išsakytą nuomonę.

- Kiekybiniai tyrimai atliekami vadovaujantis modeliuojamų veiklų stebejjimais, matematinès statistinès analizès duomenimis, anketomis ir žodinėmis apklausomis. Kiekybiniuose tyrimuose anketas patogu pateikti didelems tiriamųjų grupèms, tačiau jų atsakymų tikslumą riboja klausimo apibrezžtumas, galimi atsakymų pasirinkimai. 
Tyrimus atliekantys edukologijos mokslininkai vieningai sutaria, kad, siekiant atlikti metamokymosi, kaip švietimo objekto raiškos, gilesni pažinimą, tolimesnèse tyrimų kryptyse kiekybinių ir kokybinių tyrimų metodus tikslinga sujungti.

Metakognityvinès žinios, nuolatinis metakognityvinių igūdžių tobulinimas, mąstymas apie savo mąstymą, mokymosi reguliavimas, mokymosi problemų sprendimų paieškos, gebejjimas tiksliai ir kryptingai ieškoti reikiamos pagalbos, savo mokymosi vertinimas - pagrindiniai metamokymosi komponentai, skatinantys pradinių klasių mokinių savarankiško mokymosi gebejjimus. Metamokymosi galimybės pasireiškia ịvairiais būdais ir gali būti panaudotos pasitelkiant platų mokymosi metodų spektrą. Atliktų mokslinių tyrimų apžvalgos metu nustatyta, kad vienas svarbiausių ugdymo proceso kaitos bruožų - kognityvinès ugdymo dimensijos papildymas metakognityvine, siekiant suteikti žinių, gebejimų bei kompetencijų, kurios mokinius skatintų kritiškai mąstyti, prisitaikyti nuolat kintančių žinių pasaulyje, atlieptų kylančius iššūkius ir taptų esminès tolimesnio sẻkmingo mokymosi prielaidos. Analizuotuose tyrimuose atskleista, kad ankstyvas mažų vaikų metakognityvinis supratimas neugdomas iki pilnametystès, vèliau apskritai gali būti nerealizuojamas (Zohar ir Barzilai, 2013). Teisingai nukreipti metakognityviniai igūdžiai, prasmingas ir nuolatinis mokymasis, senų ir nuolat igyjamų naujų žinių integravimas ị igūdžius bei kompetencijas yra svarbiausi metamokymąsi mokymesi įrodantys veiksniai, kurie padeda spręsti mokymosi mokytis problemas ir ìvardyti ypatumus, leidžiančius plètoti metamokymąsi visą gyvenimą.

Nustatyta, kad ankstyvame amžiuje vaikai turi metakognityvių kompetencijų, kurias ypač svarbu pastebėti ir ugdyti, tačiau pradinio ugdymo pedagogai dèl metamokymosi koncepto tyrimų stokos ir konkrečiai neapibrěžtų tokio mokymosi konstrukcijų susiduria su daugybe iššūkių, kurie riboja sẻkmingą praktinị metamokymosi taikymą. Tyrimo metu pastebèta, jog nepaisant pastangų, kuriomis siekiama didinti sąmoningumą mokyti mokytis ir naudoti metakognityvumą, tyrimai, susiję su metamokymusi, nèra lygiaverčiai susidomėjimui jo vertinimo įrankių kūrimo procesu. Tinkamo vertinimo trūkumas trukdo tobulinti tyrimus, konceptualizuoti metamokymąsi, kuris leistų greičiau ir efektyviau pradiniame ugdyme taikyti metamokymosi praktiką.

Remiantis tyrimo rezultatais, matomas poreikis jau pradinio ugdymo lygmenyje skatinti metamokymąsi, kaip pažintinių ir mokymosi funkcijų ugdymą bei veiksmingą ịrankị susiduriant su naujais XXI amžiaus mokymosi iššūkiais. Straipsnyje pateikta mokslinių šaltinių analizė ir daromos išvados - pamatas tolesniems metamokymosi tyrimams, siekiant, kad ši mokymosi paradigma būtų plètojama ir aktyviau taikoma pradinio ugdymo procese. 


\section{Literatūra}

Akaydin, B. B., Yourulmaz, A., \& Cokcaliskan, H. (2020). Investigation of primary school students metacognitive awareness and decision-making skill. International Journal of Progressive Education, 16(4), 158-171. https://doi.org/10.29329/ijpe.2020.268.10

Annevirta, T., Laakkonen, E., Kinnunen, R., \& Vauras, M. (2007). Developmental dynamics of metacognitive knowledge and text comprehension skill in the first primary school years. Metacognition Learning, 2, 21-39. https://doi.org/10.1007/s11409-007-9005-x

Baba, Ö. M., \& Güral, M. (2016). Analysis of prospective preschool teachers' metacognitive awareness levels in terms of various variable. International Periodical for the Languages, Literature and History of Turkish or Turkic, 11(19), 107-132. http://dx.doi.org/10.7827/ TurkishStudies.9977

Bandura, A. (1989). Social cognitive theory. Annals of Child Development, 6, 1-60.

Bares, C. B. (2011). Emerging metacognitive processes during childhood: Implications for intervention development with children. Child Adolesc Soc Work, 28, 291-299. https://doi. org/10.1007/s10560-011-0233-1

Baas, D., Castelijns, J., Vermeulen, M., Martens, R., \& Segers, M. (2015). The relation between assessment for learning and elementary students' cognitive and metacognitive strategy use. British Journal of Educational Psychology, 85, 33-46. https://doi.org/10.1111/bjep.12058

Batald, K., G., \& Erbas, A. A. (2017). Investigation of primary school teacher candidates metacognitive awareness. Education of Gifted Young Scientists, 5(4), 31-48. https://dx.doi. org/10.17478/JEGYS.2017.68

Bonnett, V., Yuill, N., \& Carr, A. (2017). Mathematics, mastery and metacognition: How adding a creative approach can support children in maths. Educational and Child Psychology, 34(1), 83-93. https://www.researchgate.net/publication/312153276 Mathematics mastery and metacognition How adding a creative approach can support children in maths

Bryce, D., \& Whitebread, D. (2012). The development of metacognitive skills: evidence from observational analysis of young children's behavior during problem solving. Metacognition Learning, 7, 197-217. https://doi.org/10.1007/s11409-012-9091-2

Bryce, D., Whitebread, D., \& Szücs, D. (2015). The relationships among executive functions, metacognitive skills and educational achievement in 5 and 7 year old children. Metacognition Learning, 10, 181-198. https://doi.org/10.1007/s11409-014-9120-4

Caliskan, M., \& Sunbul, A. M. (2011). The effects of learning strategies instruction on metacognitive knowledge, Using metacognitive skills and academic achievement. Educational Sciences: Theory \& Practice, 11(1), 148-153.

Chatzipanteli, A., Grammatikopoulos, V., \& Gregoriadis, A. (2014). Development and evaluation of metacognition in early childhood education. Early Child Development and Care, 184(8), 12231232. https://doi.org/10.1080/03004430.2013.861456 
Coffman, J. L., Ornstein, P. A., McCall, L. E., \& Curran, P. J. (2008). Linking teachers' memory relevant language and the development of children's memory skills. Developmental Psychology, 44, 1640-1654. https://doi.org/10.1037/a0013859

Cornoldi, C., Carretti, B., Drusi, S., \& Tencati, C. (2015). Improving problem solving in primary school students: The effect of a training programme focusing on metacognition and working memory. British Journal of Educational Psychology, 85(3), 424-439. https://doi.org/10.1111/ bjep.12083

Diamond, A. (2002). Normal development of prefrontal cortex from birth to young adulthood: Cognitive functions, anatomy, and biochemistry. In D. T. Stuss, \& R. T. Knight (Eds.), Principles of frontal lobe function, pp. 466-503. London: Oxford University Press.

Dignath, Ch., \& Büttner, G. (2008). Components of fostering self-regulated learning among students. A meta-analysis on intervention studies at primary and secondary school level. Metacognition Learning, 3, 231-264. https://doi.org/10.1007/s11409-008-9029-x

Dignath, Ch., Büttner, G., \& Langfeldt, H. P. (2008). How can primary school students learn self-regulated learning strategies most effectively? A meta-analysis on self-regulation training programmes. Educational Research Review, 3, 101-129.

Flavell, J. H. (1979). Metacognition and cognitive monitoring: A new area of cognitive developmental inquiry. American Psychologist, 34, 906-11. https://doi.org/10.1037/0003066X.34.10.906

Flavell, J. H., Miller, P. H., \& Miller, S. A. (2002). Cognitive development. Upper Saddle. River, NJ: Pearson Education Inc.

Frenkel, S. (2014). Metacognitive components in learning to learn approaches. International Journal of Psychology: A Biopsychosocial Approach, 14, 95-112. http://dx.doi.org/10.7220/2345024X.14.5

Geurten, M., Lloyd, M. E., \& Willems, S. (2016). Hearing “quack” and remembering a duck: Evidence for fluency attribution in young children. Child Development, 514-522. https://doi. org/10.1111/cdev.12614

Gürlen, E., Turan, E., \& Senemoğlu, N. (2013). The relationship between learning approaches of prospective teachers and their academic achievement. Educational Research and Review, 8(5), 171-178. https://doi.org/10.5897/ERR12.215

Karakelle, S., \& Saraç, S. (2007). On-line and off-line assessment of metacognition. Turkish Psychological Articles, 10(20), 87-103.https://www.researchgate.net/publication/279941429 On-line and Off-line Assessment of Metacognition

Kostons, D., \& van der Werf, G. (2015). The effects of activating prior topic and metacognitive knowledge on text comprehension scores. British Journal of Educational Psychology, 85, 264-275. https://doi.org/10.1111/bjep.12069

Kuhn, D. (2000). Theory of mind, metacognition and reasoning: A life-span perspective. In P. Mitchell \& K. J. Riggs (Eds.), Children's reasoning and the mind, pp. 301-326. Hove, UK: Psychology Press.

Larkin, S. (2010). Metacognition in young children. New York: Routledge. 
Leader, W. S. (2008). Metacognition among students identified as gifted or nongifted using the discover assessment. Unpublished Doctoral Dissertation. Tucson, AZ: Graduate College of the University of Arizona.

Mansueto, G., Caselli, G., Ruggiero, G. M., \& Sassaroli, S. (2019) Metacognitive beliefs and childhood adversities: an overview of the literature. Psychology, Health \& Medicine, 24(5), 542-550. https://doi.org/10.1080/13548506.2018.1550258

Marulis, L. M., Palincsar, A. S., Berhenke, \& Whitebread, D. (2016). Assessing metacognitive knowledge in 3-5 year olds: the development of a metacognitive knowledge interview (McKI). Metacognition Learning, 11, 339-368. https://doi.org/10.1007/s11409-016-9157-7

McClelland, M., Acock, A. C., Piccinin, A., Rhea, S., A. , \& Stallings, M., C. (2013). Relations between preschool attention span-persistence and age 25 educational outcomes. Early Childhood Research Quarterly, 28 (2), 314-324. https://doi.org/10.1016/j.ecresq.2012.07.008

McClelland, M. M., \& Cameron, C. E. (2012). Self-regulation in early childhood: Improving conceptual clarity and developing ecologically Valid measures. Child Development Perspectives, 6 (2), 136-142. https://doi.org/10.1111/j.1750-8606.2011.00191.x

Mischel, W., Ayduk, O., Berman, M. G., Casey, B. J., Gotlib, H., Jonides, J., \& Shoda, Y. (2011). 'Willpower' over the life span: decomposing self-regulation. Social Cognitive and Affective Neuroscience, 6 (2), 252-256. https://doi.org/10.1093/scan/nsq081

Mylona, P. (2016). Metalearning: a contribution to theory and empirical investigation of year 4 pupils' reflections on their classrom learning. [Doctoral dissertation, University of London]. https://discovery.ucl.ac.uk/id/eprint/1502102/1/THESIS-\%20P.\%20Mylona.pdf

Moffitt, T. E., Arseneault, L., Belsky, D., Dickson, N., Robert, N., Hancox, R. J., \& Caspi, A. (2011). A gradient of childhood self-control predicts health, wealth and public safety. Proceedings of the National Academy of Sciences, 108 (7), 2693-2698. https://doi.org/10.1073/pnas.1010076108

Monkevičienė, O., Vildžiūnienè, J. ir Valinčienè, G. (2020). The Impact of teacher-initiated activities on identifying and verbalizing ways of metacognitive monitoring and control in six-year-old Children. Research in Social Sciences and Technology, 5(2), 72-92. https://doi. org/10.46303/ressat.05.02.5

Montroy, J. J., Bowles, R. P., Skibbe, L. E., McClelland, M. M., \& Morrison, F. J. (2016). The development of self-regulation across early childhood. Developmental psychology, 52 (11), 17441762. https://doi.org/10.1037/dev0000159

Morawska, A., Dittman, C. K., \& Rusby, J. C. (2019). Promoting self-regulation in young children: The role of parenting interventions. Clin Child Fam Psychol Rev, 22, 43-51. https://doi. org/10.1007/s10567-019-00281-5

Nelson, L. J., \& Fyfe, E. R. (2019). Metacognitive monitoring and help-seeking decisions on mathematical equivalence problems. Metacognition and Learning, 14, 167-187. https://doi. org/10.1007/s11409-019-09203-W

Neuenhaus, N., Artelt, C., Lingel, K., \& Schneider, W. (2011). Fifth graders metacognitive knowledge: General or domain-specific? European Journal of Psychology of Education, 26, 163-178. https://doi.org/10.1007/s10212-010-0040-7

Nieto-Marquez, N. L., Baldominos, A., \& Perez-Nieto, M. A. (2020). Digital teaching materials and their relationship with the metacognitive skills of students in primary education. Education Sciences, 10(4), 113. https://doi.org/10.3390/educsci10040113 
Piaget, J. (1954). The construction of reality in the child. New York: Basic Books.

Rieser, S., Naumann, A., Decristan, J., Fauth, B., Klieme, E, \& Buttner, B. (2016). The connection between teaching and learning: Linking teaching quality and metacognitive strategy use in primary school. British Journal of Educational Psychology, 86, 526-545. https://doi. org/10.1111/bjep.12121

Roberts, D. (2010). Learning to learn. Adult Learning, 21(6), 19-20.

Schneider, W. (2008). The development of metacognitive knowledge in children and adolescents: Major trends and implications for education. Mind, Brain, and Education, 2, 114 121. https://doi.org/10.1111/j.1751-228X.2008.00041.x

Schneider, W. (2010). Metacognition and memory development in childhood and adolescence. Metacognition, strategy use and instruction, 54-81. New York, London: Guilford Press.

Schneider, W. ir Artelt, C. (2010). Metacognition and mathematics education. ZDM Mathematics Education, 42, 149-161. https://doi.org/10.1007/s11858-010-0240-2

Schneider, W., \& Lockl, K. (2008). Procedural metacognition in children: Evidence of developmental trends. In J. Dunlosky \& R. A. Bjork (Eds.), Handbook of metamemory and memory, pp. 391-409. New York: Psychology Press.

Shamir, A., Mevarech, Z. R., \& Gida, C. (2009). The assessment of meta-cognition in different contexts:individualized vs. peer-assisted learning. Metacognition and Learning, 4, 47-61. https://doi.org/10.1007/s11409-008-9032-2

Schraw, G. (2009). A Conceptual analysis of five measures of metacognitive monitoring. Metacognition Learning, 4, 33-45. https://doi.org/10.1007/s11409-008-9031-3

Sim, Z. L., \& Xu, F. (2017). Learning higher-order generalizations through free play: Evidence from 2- and 3-year-old children. Developmental Psychology, 53(4), 642-651. doi: 10.1037/ dev0000278

Siswati, B. H, \& Corebima, A. D. (2017a, June). Study on the correlation between metacognitive skills and concept gaining of biology at several learning models. Learning \& Teaching, 18, 1-2. https://www.semanticscholar.org/paper/Study-on-the-Correlation-between-Metacognitive-and-Siswati-Corebima/93ce505582a7de5779bac6264df9d2b4acc1dfcb?p2df

Spiess, M. A., Meier, B., \& Roebers, C. M. (2015). Prospective memory, executive functions, and metacognition are already differentiated in young elementary school children. Journal of Psychology, 74 (4), 229-241. https://doi.org/10.1024/1421-0185/a000165

Stonkuvienè, G. (2018). Mokèjimo mokytis samprata ir kontekstas ikimokyklinių įstaigų ugdymo programose. Pedagogika, 131 (3), 110-128. http://dx.doi.org/10.15823/p.2018.37

Suminto, E. A., \& Mbato, C. L. (2020). The implementation of metacognition in teaching character education in primary education. Journal of Language Teaching and Learning, Linguistics and Literature, 8, 230-246. doi:10.24256/ideas.v8i1.1255

Tarrant, P., \& Holt, D. (2016). Metacognition in the primary classroom. New York, United States: Routledge.

Veenman, M. V. J. (2011). Learning to self-monitor and self-regulate. In R. Mayer \& P. Alexander (Eds.), Handbook of research on learning and instruction, pp.197-218. New York: Routledge.

Vygotsky, L. S. (1978). Mind in society: The development of higher psychological processes. Cambridge, MA: Harvard University Press.

Zheng, J. (2017). Application of metacognitive strategy to primary listening teaching. Earth and Environmental Science 100, 12-17. https://iopscience.iop.org/article/10.1088/1755-1315/100/1/012017/meta

Zimmerman, B. J. (1990). Self-regulated learning and academic achievement: An overview. Educational Psychologist, 25 (1), 3-17. https://doi.org/10.1207/s15326985ep2501_2 
Zohar, A., \& Barzilai, S. (2013). A review of research on metacognition in science education: current and future directions. Studies in Science Education, 49(2), 121-169. https://doi.org/ $\underline{10.1080 / 03057267.2013 .847261}$

\title{
Meta-Learning in Primary Education: A Scientific Literature Analysis
}

\author{
Jovita Matulaitienè \\ Vytautas Magnus University, Faculty of Social Sciences, K. Donelaičio g. 58, LT-44248 Kaunas, Lithuania, \\ jovita.matulaitiene@alumni.vdu.lt
}

\section{Summary}

The article analyses the self-study of primary school students, aims to name the applied meta-learning methods, the challenges that arise and the further direction of research that would allow developing the application of meta-learning in primary education. The research aim - to reveal what research is being carried out, what we know about the self-study of primary education students in Europe and other countries.

Research data and theoretical reviews from electronic education databases of Academic Search Complete (EBSCO), Cambridge Core, Education Source (EBSCO), ERIC and Science Direct were analysed in order to achieve the aim of the research. To create an overview of different studies, the articles were content-encoded by briefly describing the main features and results of each study.

The results of the scientists of educational science research allow stating that even at an early age, meta-learning has a positive impact on the development of children in the fields of reading, language learning, math, science and problem-solving. Based on the results of the study, there is need to promote meta-learning as a tool to develop cognitive and metacognitive skills and to face the challenges of learning in the 21 st century. The analysis and conclusions of scientific sources are provided in the article as a base for further studies on meta-learning, aiming that this learning paradigm would be developed and would allow to overcome the emerging difficulties of learning and become individuals who know how to learn.

Keywords: primary education, meta-learning, metacognitive strategies, metacognitive awareness, metacognition in childhood. 